Article

\title{
Net Neutrality, the Fairness Doctrine, and the NRB: The Tension between United States Religious Expression and Media Regulation
}

\author{
Kathryn Montalbano \\ Communication and Digital Media, Neumann University, Aston, PA 19063, USA; E-Mail: montalbk@neumann.edu
}

Submitted: 29 September 2017 | Accepted: 15 November 2017 | Published: 9 February 2018

\begin{abstract}
This article analyzes the historical continuity between the opposition of the National Religious Broadcasters (NRB) to the Fairness Doctrine (1949) and to the contemporary Federal Communications Commission (FCC) Open Internet principle, net neutrality. These debates demonstrate how media policy discourse has shaped democratic ideals, including by designating whose voices are or are not included in broadcast and digital communication spaces. The discourse emerging from both media policy debates reveals that fears concerning cultural hegemony and the diversity of expression in the United States have intertwined with fears concerning the invasion of foreign ideologies. The article then considers the possibility of reconciling religious and secular discourse in the mediated public sphere.
\end{abstract}

\section{Keywords}

evangelicals; Fairness Doctrine; Federal Communications Commission; media regulation; National Religious Broadcasters; net neutrality; public sphere; radio; religion; secularism

\section{Issue}

This article is part of the issue "Media History and Democracy", edited by David W. Park (Lake Forest College, USA).

(C) 2018 by the author; licensee Cogitatio (Lisbon, Portugal). This article is licensed under a Creative Commons Attribution 4.0 International License (CC BY).

\section{Introduction}

The Federal Communications Commission (FCC) net neutrality rules (2017, para. 2) aim to ensure the Open Internet by prohibiting Internet Service Providers (ISPs) from blocking access to legal content, applications, or services; throttling lawful Internet traffic; and favoring Internet traffic that benefits their own interests. Robert McChesney's (2007, pp. 184-185) characterization of net neutrality provides a useful framework for analyzing the opposition of the National Religious Broadcasters (NRB) to both net neutrality and the Fairness Doctrine:

The story was too often miscast in the press as a corporate clash of the titans-Google versus AT\&T, or Yahoo! versus Verizon-when the real story was the unprecedented involvement in a media policy issue from the grassroots.

Observing media policy debates at the grassroots reveals not only how actors directly effect change, but the ways in which media policy discourses have shaped democratic ideals, including by designating whose voices are or are not incorporated into broadcast and digital communication spaces.

Evangelical broadcasters and leaders formed the NRB in 1944 in response to the influence of the Federal Council of Churches, now the National Council of Churches, which convinced United States radio networks to deny evangelical broadcasters access to the airwaves for failing to serve the public interest and use the airwaves responsibly. As E. Brandt Gustavson, NRB President from 1990 to 2001, testified before the House (Religious Broadcasting Freedom Act and the Noncommercial Broadcasting Freedom of Expression Act of 2000, 2000 , p. 20), the Federal Council of Churches had tried to "strike an agreement with the networks and the large stations in communities across the Nation to act as gatekeeper for all religious programming". These events preceded the Fairness Doctrine (1949), which formalized this framework for broadcast communication through two principles. Broadcasters had to: (1) cover controver- 
sial issues of public interest, and (2) provide balanced accounts by allotting free time to opposing voices. It was a response both to the dissemination of propaganda on the airwaves abroad in Nazi Germany and Fascist Italy, foreshadowing the rhetorical intertwining of media policy and allegedly pernicious Islamic ideology in twenty-first-century NRB discussions about net neutrality, as well as to racial and religious attacks at home, such as those cultivated by the anti-Semitic priest, Father Coughlin, in the early 1930s. The NRB, nonetheless, characterized the Fairness Doctrine as censorship of religious expression.

The NRB praised the decision of Ajit Pai, the current FCC chair, to regulate the Internet through a small government approach. In July of 2017, NRB President Jerry Johnson appealed to the FCC to minimize Internet regulation and reduce Title II powers as a means of promoting global Internet freedom (Johnson, 2017, p. 2). The NRB has repeatedly argued against the use of Title II to regulate ISPs (Parshall, 2014, p. 3). The connection to United States foreign policy in the NRB stance on net neutrality traces back to its concern about the Fairness Doctrine, which was also laced with Republicaninfused rhetoric about foreign policy. Discourse emerging from the net neutrality debates, drawing from the possibility of a revived Fairness Doctrine and the concerns NRB leaders had previously harbored about the policy in the mid-twentieth century, reveals the fears of the NRB about cultural hegemony and free expression at home alongside peripheral fears concerning the invasion of foreign ideologies.

\section{Religious-Secular Conflict in Unites States Media Policy}

\subsection{Theoretical Framework}

José Casanova (1994, p. 53) wrote in his sociological analysis of modern religions that, "by the 1830 s, evangelical Protestantism, organized denominationally, had become de facto the culturally, though not politically, established American religion". By the twentieth century, however, the contributions of the NRB to media policy debates demonstrate how an evangelical organization - that was not even mainstream Protestant-had evolved to execute both cultural and political agency in the United States. NRB leaders believed they could feasibly challenge the boundaries between secularism and religion through the policies governing the radio and Internet, respectively. NRB opposition to both the Fairness Doctrine and net neutrality not only constituted explicit critiques of media policy, but also tacit critiques of secularism in the public sphere.

Charles Taylor (2007) argued that secularism arose with the increase of alternative options of beliefs, as well as with cultural shifts in ideas toward the religious and the secular. Secularization, for Taylor, is therefore a byproduct of religious processes. This distinction would be important for NRB leaders who are critical of how media policy is itself rooted in a legal, cultural framework that seemingly treats secularization as replacing an "enchanted world". For example, Taylor (2011, pp. 35, 40-41) noted that legal formulas such as the religion clauses in the First Amendment are built on tensions, showing that "there is no such set of timeless principles that can be determined...by pure reason alone" and without conflicts. Secular laws and cultures include many different goals that often collide with one another, which the disparity between censorship of free expression, as characterized by the NRB, and regulation of content for the public interest, as characterized by the FCC, demonstrates.

Taylor (2007, p. 451) detailed the ways in which religion is always secularizing, including through evangelicalism, which he characterized as, historically, "basically an anti-hierarchical force, part of the drive for democracy". This characterization is perhaps a rather appropriate way to frame how NRB leaders have understood their role as protectors of conservative, fundamentalist views in the public sphere, fighting for balanced, democratic discourse through media policy. This article seeks to extend Taylor's framework by probing, as the NRB has done, the position of all religious citizens in the United States public sphere, including those who do not espouse mainstream, conventional ideologies, and the role of media policy in defining that position.

\subsection{The Rise of the NRB in a Mediated Public Sphere}

The NRB formed in the 1940s, uniting fundamentalist groups as a direct response to the Federal Council of Churches, which claimed to speak for all Protestants. The opposition of the NRB to both the Fairness Doctrine and net neutrality is instructive of how it has challenged mainstream Protestantism through media policy. By the mid-1940s, the NRB had become "the nucleus of a vibrant media subculture both serving the growing evangelical movement and popularizing its worldviewdevelopments that were hard won by forties commercial religious broadcasters" (Hangen, 2002, p. 141). By 1947, two prominent issues regarding conservative religious voices on the radio had surfaced: first, whether religious broadcasters, in particular, Christian station owners, should be able to use controversial language in broadcasts and editorial opinions; and second, whether conservatives were unfairly denied access to the airwaves.

Religious radio paved the path for evangelical voices to enter the public sphere (Hangen, 2002, p. 158). Steiner (2016, p. 184) has observed the ongoing role of radio in evangelical culture: "even a generation after the dawn of the digital age, the 'old media' of radio continues to have a key role in setting the evangelical agenda". Additionally, religious radio has shaped the evangelical agenda regarding media policy, as the legacy of the Fairness Doctrine debates have shaped contemporary NRB opposition to net neutrality. Ward (in press, p. 2) insightfully ar- 
gues: "NRB opposition to net neutrality arguably reflects the fact that the 'electronic church' has, like the rest of the media industry, become consolidated". In other words, religious media conglomerates would be able to pay large fees that would increase in the absence of net neutrality (Ward, in press, pp. 3-4), thereby explaining why key actors in the religious media industry, such as the NRB, might oppose net neutrality.

\subsection{Negotiating Net Neutrality}

The irony of NRB opposition to the Fairness Doctrine and net neutrality, two policies that have protected or aim to protect minority or non-commodifiable viewpoints, lies in the history of the NRB as a disempowered collection of voices that sought to carve its space in the mediated public sphere. To further complicate that irony, the NRB at points has supported net neutrality-when its leaders believed the principle could transform in accordance with NRB interests. For example, it joined the Savethelnternet.com coalition, formed by the Free Press in 2006, as an advocate of free speech (McChesney, 2007, p. 184). The NRB penned a letter to Chairman Sensenbrenner in April of 2006 expressing its support for network neutrality protections (Network Neutrality: Competition, Innovation, and Nondiscriminatory Access, 2006). In May of the same year, the NRB firmly supported net neutrality alongside left-wing coalitions (S. 2686, Communications, Consumer's Choice, and Broadband Deployment Act of 2006 (part II), 2006). During a 2006 Senate Commerce, Science, and Transportation Committee hearing, Frank Wright, NRB President from 2003 to 2013, officially endorsed net neutrality. Wright had submitted a letter to the chairman, Hon. Ted Stevens, in support of the renomination of Kevin Martin as Commissioner and Chairman of the FCC, while acknowledging that the NRB and FCC did not always coexist in perfect harmony: "While NRB members have not seen every issue before the FCC go their way, we have always found an open door to make our thoughts and concerns known" (Nominations to the Federal Communications Commission and to the Department of Commerce [National Telecommunications and Information Administration], 2006, p. 41).

In 2010, one year before the escalation of the 2011 net neutrality debates, the NRB founded the John Milton Project for Religious Free Speech in response to alleged threats of anti-Christian censorship on new media platforms. One year later, senior NRB vice president, Craig Parshall, discussed in a white paper report for the Project how media policies of technology companies undermined the First Amendment. Parshall characterized the "Open Internet" as inadequate in addressing new media platforms, as well as filled with "broad, complex, free market-inhibiting rules with vague standards of application, and short on the provision of basic guarantee to citizen users that their content will not be censored because their ideas are unpopular, controversial, or politically incorrect" (NRB, 2011, p. 4). The NRB (2011, p. 8) sought greater regulation of new media platforms that otherwise limited "lawful religious expression".

Parshall also lamented the lack of support from the ACLU in acknowledging "anti-Christian censorship" (NRB, 2011, p. 7). It supported new media regulation, but not the particular iteration of net neutrality that already existed at that time (NRB, 2011, p. 7). Rather than embracing regulation of ISPs, the NRB wanted governmentpromoted, uninhibited speech built into the rules of new media businesses, such as Google or Facebook. Citing Rob Frieden, Professor of Telecommunications and Law at Pennsylvania State University, Parshall contemplated the lack of concern for free speech and religious expression in the FCC Open Internet rules: "his primary concern is that the FCC's rules should serve to 'safeguard competition,' admittedly an important principle, but at the same time [it is] an approach that fails to recognize the fundamental free speech rights of citizen users" (NRB, 2011, p. 8). He suggested that FCC regulation of digital media businesses would have to parallel government regulation of public utilities (NRB, 2011, p. 13). In short, he declared: "the actual provisions of the Order fail to implement any real protections for free speech" (NRB, 2011, p. 29).

\subsection{Fearing the Resurrection of the Fairness Doctrine}

This fixation of NRB leadership on "free speech" traces back to the Fairness Doctrine. The legacy of the Fairness Doctrine within the NRB remains central to the means by which its leaders have resisted net neutrality. For decades after the Fairness Doctrine became law in 1949, the FCC avoided disputes regarding whether religion was even an issue of fairness (Gentry, 1984, p. 262). A handful of cases in the late 1920s to the early 1930s contributed to the rise of the Fairness Doctrine. By the postwar 1940s, as Pickard (2013) has shown, a broadcast reform movement that included religious organizations (and, in particular, liberal Protestants, led by Everett Parker), laid the foundation for the Fairness Doctrine and other future radio reform. FCC Commissioner, Clifford Durr, acknowledged that United States radio at the time did not consider the voices of many, including religious minorities (Pickard, 2013, pp. 318-319). Hendershot (2011, p. 140) has argued that the FCC was largely reactive by implementing the Fairness Doctrine, passively responding to only a few of the handful of citizen complaints. The Fairness Doctrine was designed to fail, Hendershot (2011, p. 18) added, "in part, because it was an attempt to serve an inchoate idea of the public". Pickard's (2015, p. 122) similar analysis of the Fairness Doctrine has confirmed that a "vague public interest obligation", rather than a concerted effort to fortify public interest standards, has shaped United States mass media industries today. This ambiguous framework has particularly neglected the voices of those who fall beyond the purview of the public interest.

At the core of the NRB religiously-motivated argument against the Fairness Doctrine was the idea that 
broadcasters should receive First Amendment protection. In 1975, Reverend James Nicholls testified before the Subcommittee on Communications against the Fairness Doctrine. His frank testimony suggests that the battle for religious expression on the airwaves, led by the NRB, was not merely a fight for the freedom of uncontested religious speech, but a far more complex religious battle over the survival of less powerful Christian denominations through mass media, very much reflecting the marketplace of religion itself. Nicholls was represented by Benedict P. Cottone, the lawyer for Carl Mclntire and a former advocate of the Fairness Doctrine. Cottone had become a "strong opponent of the doctrine" (Hendershot, 2011, p. 146). He mused on the problems of the Fairness Doctrine for religious broadcasters who espoused "unpopular" religious or political ideologies, and whom he characterized as "a frustrated minority...trying desperately to get their voices heard" (Hendershot, 2011, p. 325) but were afraid of being censored. Nicholls had conducted a survey of the broadcasters at the 1975 NRB Convention, as well as of the attendees at the annual Christian Beacon Press convention (Fairness Doctrine, 1975, pp. 318-319). From this survey, Reverend Nicholls claimed to have discovered that, of these respondents, 73.3\% believed the Fairness Doctrine abridged the First Amendment; $80 \%$ believed the Fairness Doctrine limited speech in broadcast media; and $73.3 \%$ believed the Fairness Doctrine censored speech in America, broadly speaking (Fairness Doctrine, 1975, pp. 332-333). The rigor of his study is indeterminable, but his attempt to offer these findings as evidence suggests he recognized the NRB as a representative, if not central, example of conservative, evangelical public opinion.

FCC chairman Mark Fowler, whose goal was "to eliminate government action that infringes the freedom of speech and the press" by creating an unregulated, free market (Jung, 1996, p. 32), appealed to the NRB on February 9, 1982, for its support to repeal the doctrine: "spectrum scarcity has been used as an excuse to regulate, not a reason!" (Jung, 1996, p. 40). He viewed the policy as excessive government intervention and characterized spectrum scarcity as a facade constructed by an antireligious FCC. Between 1983 and 1985, broadcasters and media organizations more publicly opposed the doctrine, concerned about appealing to the largest public possible rather than minority voices, such as those of the NRB, whose unpopular ideas were less commodifiable for advertisers (Jung, 1996, p. 108).

Nonetheless, the legacy of the Fairness Doctrine did not die with the 1987 repeal but intensified during the 2011 net neutrality debates, thereby demonstrating the cultural and legal significance of radio to the NRB. In this year, the NRB consistently published press releases to its official Web site denouncing net neutrality. NRB President Frank Wright (2011, para. 2) penned a letter implying that, in the heat of the net neutrality debates, the NRB was largely concerned about the Fairness Doctrine resurfacing in other arenas: "Now that the letter of this rule has been eliminated, NRB stands ready to work with you to ensure that the spirit of the Fairness Doctrine does not creep into other rules or proceedings".

Fear within the NRB resurfaced with the Fairness in Broadcasting Act of 1993. A Democratic representative from North Carolina, W. G. Hefner, advocated for the amendment of the Communications Act of 1934 by supporting the reinstatement of the Fairness Doctrine with his Fairness in Broadcasting Act of 1993, much to the distress of the NRB. The NRB did not know that just a few years later, the Telecommunications Act of 1996 would effect an even more monumental overhaul of media law since the Communications Act of 1934 , one that would decrease the number of independent syndicators and, consequently, lesser known preachers (Ward, 2009, p. 94).

E. Brandt Gustavson, NRB President from 1990 to 2001, opposed the reinstatement of the Fairness Doctrine before the House in 1993 (Broadcasters and the Fairness Doctrine, 1993, pp. 39-41). He attempted to reconfigure the public sphere as the participation of the most number of people, including minority voices, rather than the participation of the most while accounting for the maximum number of interests at one time. He claimed that since the repeal of the Fairness Doctrine, small religious stations had flourished, benefitting the nation by removing barriers to free exercise of religion and discussion of controversial issues (Broadcasters and the Fairness Doctrine, 1993, p. 39). However, he warned that government interference with religious broadcasting remained due to the "cultural environment" in which "many traditional topics of religious teachings" had "become highly controversial" (Broadcasters and the Fairness Doctrine, 1993, p. 39). Gustavson's understanding of "traditional" resided at the core of the issue, that is, whether non-traditional religious identities needed to conform to the mainstream values of the public sphere.

In an NRB white paper submitted for this hearing, "Statutory Reimposition of the 'Fairness Doctrine' Would be Unconstitutional", the NRB praised the increase of direct citizen participation through radio call-in formats "that was never before possible" (Broadcasters and the Fairness Doctrine, 1993, p. 40), following the repeal of the Fairness Doctrine. This priority within the media policy agenda of the NRB demonstrated that it was concerned with unveiling the discussion of private matters: "sexual morality, marriage, parental responsibility, and the sanctity of human life are now hotly contested by an increasingly secularized society" (Broadcasters and the Fairness Doctrine, 1993, pp. 40-41). In a 2007 updated version of this white paper with the same title, Frank Wright, then NRB President, even went so far as to predict that, should the Fairness Doctrine resurface, it could lead to a "continuing state surveillance" that ensured religions broadcasters adhered to the fairness guidelines: "such a pervasive 'entanglement' of government regulators into the speech of religious entities would be incompatible with the religious liberties protected by the First Amendment" (NRB, 2007, p. 12). 
Gustavson's testimony (Broadcasters and the Fairness Doctrine, 1993, pp. 39-40) showed that the NRB tried to redefine the boundary drawn around the organization despite acknowledging that the religious community was itself diverse and entitled to access to the airwaves. He suggested unity amongst all conservative religious groups against their progressive counterparts:

In making this argument on behalf of religious liberty, we would like to stress that NRB is not advocating rights that are beneficial only to one side of a public policy debate. In fact both sides of our Nation's cultural divide are well represented in the religious broadcasting community....Both camps currently benefit from their ability to have access to the airwaves free of governmental oversight and supervision.

He rhetorically denounced the Fairness Doctrine as "a government-mandated system of enforced fairness" (Broadcasters and the Fairness Doctrine, 1993, p. 40), and therefore a hindrance to uninhibited religious expression, which subsequent NRB rhetoric concerning net neutrality would mimic. Edward J. Markey of the Committee on Energy and Commerce, nonetheless, assured Gustavson that the Fairness Doctrine would not apply to broadcasters wishing to present controversial viewpoints regarding religious issues (Broadcasters and the Fairness Doctrine, 1993, p. 66). Several years later, Gustavson would testify in support of the Religious Broadcasting Freedom Act and the Noncommercial Broadcasting Freedom of Expression Act of 2000 against the FCC, which had "overstepped its authority" by making decisions that restricted the "fundamental freedom of religious expression" (The Religious Broadcasting Freedom Act and the Noncommercial Broadcasting Freedom of Expression Act of 2000, 2000, p. 20). Gustavson channeled anti-elitist, populist rhetoric, endorsing a more aggressive approach to creating a religion-friendly, mediated environment that accounted for religious minorities when crafting media policies in the public interest (The Religious Broadcasting Freedom Act and the Noncommercial Broadcasting Freedom of Expression Act of 2000, 2000, p. 21):

Thus, in effect, the FCC created a category of politically correct government-approved, religious speech and that is abhorrent to us and unacceptable. Essentially, the FCC seems to think it is permissible for programs to talk all about religion in academic or intellectual terms but when the programs become more passionate, emotional, personal or originates from a church, it is somehow less educational, instructional or cultural.

Nonetheless, the support of the NRB for these acts did not avoid criticism. In a written rebuttal presented at this hearing by a sociology professor and co-chair of the Save Pittsburg Public Television Campaign, Starr argued that the NRB was a predator, not a victim, since educational licenses were reserved for the whole community (The Religious Broadcasting Freedom Act and the Noncommercial Broadcasting Freedom of Expression Act of 2000,2000 , p. 60). Starr's rebuttal suggests that, from an outsider's perspective, the NRB wanted to redefine the "public sphere" to one that supported the rights of the few to voice their opinions, even if it threatened the well-being of the many.

\subsection{Thwarting the Threat of Foreign Ideologies}

One of the most powerful political allies of the NRB was President George W. Bush. President Bush attended the annual NRB convention in 2008, characterizing the Fairness Doctrine as a question of the freedom of speech and religion alongside a broader discussion of the World Trade Center attacks. Bush characterized the prospect of reinvigorating the Fairness Doctrine as "an effort afoot that would jeopardize your right to express your views on public airways" and require many programs to "meet Washington's definition of balance" (White House, 2008, para. 9). He then shifted to discussing violent extremism in the Middle East, "the region of the world that is the least free" (White House, 2008, para. 14) and that cultivated the suicide bombers of September 11, 2001, "directly" (White House, 2008, para. 16) affecting United States safety. Hibbard (2010, p. 196) has characterized Bush at this convention as having portrayed United States power as a "fundamentally benign force in the world that is '[once again] called into action for the defense of liberty'". Hibbard demonstrated, through this example, how the United States has systematically garnered domestic support from groups such as the NRB in order to justify its discourse and policies regarding Islamo-fascism and dysfunction in the Middle East and South Asia.

At the 2011 NRB Convention, attended by NRB ally James Dobson and NRB President Frank Wright, John Boehner (2011) adopted Bush's 2008 rhetoric of freedom to criticize the Fairness Doctrine by amassing support for United States foreign policy. The merging of religion and politics in the rhetoric of Republican leaders, a common tactic employed when communicating with religious conservatives, seemingly persuaded an already defensive NRB that ideological and militaristic foreign invasion threatened the cultural, political center of the United States. In addressing the national debt, Boehner predicted that the FCC may serve "as Internet traffic controller" and possibly run "roughshod over local broadcasters" who had provided "free content" to their communities for decades (Boehner, 2011, para. 22). In discussing net neutrality, he linked the freedom of expression in the United States to the repression of free thought and economic suppression of the national debt, much as Bush linked his Fairness Doctrine speech to Islamic suppression of free thought in the Middle East. Boehner (2011, para. 57) claimed: "gone is our culture of 
independence-in its place, a cycle of dependence". He also strategically addressed a point of interest to the NRB: the persecution of "religious minorities in Iraq" (Boehner, 2011, para. 108), given the organizational identity of the NRB itself as a persecuted religious minority within its own homeland.

This point of interest provided a segue to discussing net neutrality as an attack on the expression of religious minorities that would allow the FCC "free reign" (Boehner, 2011, para. 21): "right now, freedom and free expression are under attack by a power structure in Washington populated with regulators who have never set foot inside a radio station or a television studio" (Boehner, 2011, para. 19). Boehner (2011, para. 24), speaking on behalf of the House Republicans, encouraged the NRB to combat the FCC through Congress: "as far as I'm concerned, there is no compromise or middle ground when it comes to protecting our most basic freedoms". He furthermore connected this larger conversation to the Fairness Doctrine, "another threat to freedom with an innocuous name" (Boehner, 2011, para. 31) and a "censorship scheme from the 1940s" that represented "Washington's definition of 'balance"" (Boehner, 2011, para. 32), that is, an attempt by Congress "to silence ideas and voices they don't agree with" (Boehner, 2011, para. 36). Although neither President Obama nor Congress showed interest in reviving the Fairness Doctrine, the NRB welcomed Boehner's critique of a government trying to regulate the media in order to craft its own vision of a fair and balanced mediated public sphere.

\section{Conclusion}

Jürgen Habermas (2011, pp. 25-26) recognized that, although religious reasons are insufficient for substantiating arguments in the public sphere, citizens could translate religious language of public reason in order to provide a common moral ground in the public sphere. This framework for compromise suggests that the NRB failed to effectively achieve its goals in broadcast and digital media policy because it neglected to translate its religious discourse into the language of public reason, while instead attempting to either restructure or even eradicate media policy conflicting with its organizational goals. Taylor (2011, pp. 36-37) disagreed with Habermas by claiming that religious belief should not receive special status over nonreligious belief, since these disagreements could not be resolved through public reason. The tension between these two approaches for reconciliation provides a theoretical framework for understanding the connection between the Fairness Doctrine and net neutrality in the history of the NRB.

The Fairness Doctrine fostered a media environment in which diverging viewpoints remained distinctive but balanced. NRB leaders' resistance to net neutrality has been seemingly non-rational but consistent with an environment of religious media conglomeration (Ward, in press, pp. 3-4). Additionally, NRB discourse fused domestic concern for freedom of expression with the militaristic concern for freedom from foreign invaders, a tactic frequently employed by Republican politicians in discussion with conservative religious figures. Yet through government regulation, net neutrality protects NRB content and delivery from both economic as well as cultural constraint, such as by preserving delivery of the content on the NRB Web site directly or, more indirectly, the content of streaming video "intervangelist" preachers who have replaced NRB-supported 1960s televangelists (Bekkering, 2011, p. 105). Megachurches that have streamed religious services online raise new problems for ISPs seeking to fairly implement net neutrality, such as the rise in conflicts occurring between evangelical Christian broadcasters and Islamic leaders, who feel their communities are targets of this broadcasting (Wikle, 2015).

Secularism, according to Taylor (2007, p. 53), has not displaced religion but rather constitutes a byproduct of religion itself. Even prior to the rise of Habermas's public sphere, medieval reform in the Catholic Church tried to reconcile the disparity between the elites and masses, much as the Reformation challenged the status quo of Catholicism, thereby secularizing societies using the very fabrics of religion itself (Taylor, 2007, p. 82), rather than, as the common narrative claims, supplanting religion. The obligation to speak truthfully in the United States press was partially rooted in religious beliefs, noticeably in the significant Zenger (1735) trial that helped to shape the First Amendment: "The Zenger case, then, was as much a religious as a political or legal phenomenon" (Nord, 1985, p. 15), demonstrating that religious and secular matters were, in fact, interlaced in language in the emerging United States public sphere. Talal Asad (2003) similarly noted that secularism is a byproduct of religious endeavors, but he critiqued the Western, Christian lens through which scholars have distinguished between religion and secularism, and which itself has a politicized history. This history has contributed to a secular myth of liberal democracy, excluding non-Western religions from the discourse of public reason by embracing "only religions that have accepted the assumptions of liberal discourse" (Asad, 2003, p. 183). Asad's critique is particularly indispensable for future research on the place of Islam in United States public discourse and media policy.

These critiques of secular discourse prompt us to trace its legal, political, and cultural history in the United States to reconsider precisely what secularism means in media policy that organizes societies, shapes communicative practices, and governs public discourse. Contemporary media policymakers aiming to reconcile tensions between religious and non-religious beliefs in the mediated public sphere might consider whether a myopic engagement with secularism overlooks the intertwining of religious and secular concerns that have historically shaped religiously-grounded freedom of expression cases, overshadowed by the secular victors. Such heightened awareness could enable media policymak- 
ers to better understand the stakes that religious actors perceive-justified or not-in media policy debates.

\section{Acknowledgments}

I would like to thank Randall Balmer, Pat Farabaugh, and Ann Neumann for their ideas and inspiration in the preliminary stages of this research. I would also like to thank Courtney Bender and Samuel Cruz for providing me with the theoretical framework to illuminate this analysis of religion in media policy. I owe a special thank you to Mark Ward Sr. for graciously sharing access to his work in accordance with the open access philosophy that supports this very journal. I am extraordinarily grateful to my graduate school mentor, Richard R. John, for his unwavering support, as well as to Brian Dolber, Dave Park, and Ben Peters, for sharing my belief in the contribution of religion and media scholarship to our field. Finally, thank you to the editors and staff of Media and Communication for supporting me in the beginning of my scholarly career.

\section{Conflict of Interests}

The author declares no conflict of interests.

\section{References}

Asad, T. (2003). Formations of the secular: Christianity, Islam, modernity. Palo Alto, CA: Stanford University Press.

Bekkering, D. J. (2011). From 'televangelist' to 'intervangelist': The emergence of the streaming video preacher. The Journal of Religion and Popular Culture, 23(2), 101-117.

Boehner, J. (2011). Boehner's speech to the National Religious Broadcasters on Washington's spending binge (Congressional Documents and Publications). Lanham, MD: Federal Information \& News Dispatch, Inc.

Broadcasters and the Fairness Doctrine: Hearing before the Subcommittee on Telecommunications and Finance of the Committee on Energy and Commerce, 103rd Cong. 39 (1993) (testimony of E. Brandt Gustavson).

Casanova, J. (1994). Public religions in the modern world. Chicago, IL: University of Chicago Press.

Fairness Doctrine: Hearings before the Subcommittee on Communications of the Committee on Commerce, 94th Cong. 314 (1975) (testimony of Reverend James Nicholls).

Federal Communications Commission. (2017, September 8). The open Internet. FCC. Retrieved from https:// www.fcc.gov/consumers/guides/open-internet

Gentry, R. H. (1984). Broadcast religion: When does it raise Fairness Doctrine issues? Journal of Broadcasting, 28(3), 259-270.

Habermas, J. (2011). "The political": The rational meaning of a questionable inheritance of political theology. In E. Mendieta \& J. VanAntwerpen (Eds.), The power of religion in the public sphere (pp. 15-33). New York, NY: Columbia University Press.

Hangen, T. J. (2002). Redeeming the dial: Radio, religion, \& popular culture in America. Chapel Hill, NC: University of North Carolina Press.

Hendershot, H. (2011). What's fair on the air? Cold War right-wing broadcasting and the public interest. Chicago, IL: University of Chicago Press.

Hibbard, S. (2010). Islamo-fascism and America's long war. Journal of Islamic Culture and Law, 11(3), 195-211.

Johnson, J. A. (2017). In the matter of restoring Internet freedom (WC Docket No. 17-108). Washington, DC: United States Government.

Jung, D. J. (1996). The Federal Communications Commission, the broadcast industry, and the Fairness Doctrine, 1981-1987. New York, NY: University Press of America.

McChesney, R. (2007). Communication revolution: Critical junctures and the future of media. New York, NY: The New Press.

National Religious Broadcasters. (2007). Statutory reimposition of the 'Fairness Doctrine' would be unconstitutional. Washington, DC: Frank Wright.

National Religious Broadcasters. (2011). True liberty in a new media age: An examination of the threat of antiChristian censorship and other viewpoint discrimination on new media platforms. Washington, DC: Craig Parshall.

Network Neutrality: Competition, Innovation, and Nondiscriminatory Access: Hearing before the Task Force on Telecom and Antitrust of the Committee on the Judiciary, 109th Cong. 1 (2006).

Nominations to the Federal Communications Commission and to the Department of Commerce ( $\mathrm{Na}$ tional Telecommunications and Information Administration): Hearing before the Committee on Commerce, Science, and Transportation, 109th Cong. 1 (2006).

Nord, D. P. (1985). The authority of truth: Religion and the John Peter Zenger case. Journalism Quarterly, 62, 227-235.

Parshall, C. (2014). Protecting and promoting the Open Internet (GN Docket No. 14-28). Washington, DC: United States Government.

Pickard, V. (2013). "The air belongs to the people": The rise and fall of a postwar radio reform movement. Critical Studies in Media Communication, 30(4), 307-326.

Pickard, V. (2015). America's battle for media democracy: The triumph of corporate libertarianism and the future of media reform. New York, NY: Cambridge University Press.

Religious Broadcasting Freedom Act and the Noncommercial Broadcasting Freedom of Expression Act of 2000: Hearing before the Subcommittee on Telecommunications, Trade, and Consumer Protection of the Committee on Commerce, 106th Cong. 20 (2000) (testimony of E. Brandt Gustavson). 
S. 2686, Communications, Consumer's Choice, and Broadband Deployment Act of 2006 (part II): Hearing before the Committee on Commerce, Science, and Transportation, 109th Cong. 1 (2006).

Steiner, M. A. (2016). A research agenda of the electronic church in the digital age. In M. Ward, Sr. (Ed.), The electronic church in the digital age: Cultural impacts of evangelical mass media (Vol. 1, pp. 1-26). Santa Barbara, CA: Praeger.

Taylor, C. (2007). A secular age. Cambridge, MA: The Belknap Press of Harvard University Press.

Taylor, C. (2011). Why we need a radical redefinition of secularism. In E. Mendieta \& J. Van Antwerpen (Eds.), The power of religion in the public sphere (pp. 34-59). New York, NY: Columbia University Press.

Ward, M., Sr. (2009). Dark preachers: The impact of radio consolidation on independent religious syndicators. Journal of Media and Religion, 8(2), 79-96.

Ward, M., Sr. (in press). Digital religion and media eco- nomics: Concentration and convergence in the electronic church. Journal of Religion, Media, and Digital Culture, 1-18.

White House. (2008, March 11). President Bush attends National Religious Broadcasters 2008 convention [Press release]. Retrieved from https://georgewbushwhitehouse.archives.gov/news/releases/2008/03/20 080311-3.html

Wikle, T. (2015). Technology and the changing geography of religious media. In S. Brunn (Ed.), The changing world religion map (Vol. 15, pp. 3751-3764). New York, NY: Springer.

Wright, F. (2011, August 24). Frank Wright to Michael J. Copps, Mignon Clyburn, Julius Genachowski, and Robert M. McDowell [Letter, identical copies]. Retrieved from http://content.nrb.org/Webdocs/ Advocacy/FCC_Chairman_Commissioners_Letter_8_ 24_11.pdf

\section{About the Author}

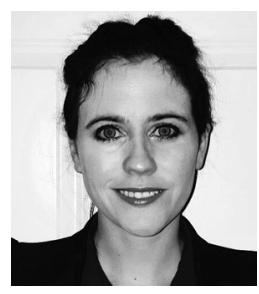

Kathryn Montalbano is an Assistant Professor of Communication and Digital Media at Neumann University in Aston, Pennsylvania. Her research centers on religion and media, communication history, and media policy. Currently, she is writing her first book (under contract with Routledge), in which she compares how United States government agencies in the nineteenth, twentieth, and twenty-first centuries monitored the religious expression of Mormons, Quakers, and Muslims, respectively. She received her PhD in communications in 2016 from Columbia University. 